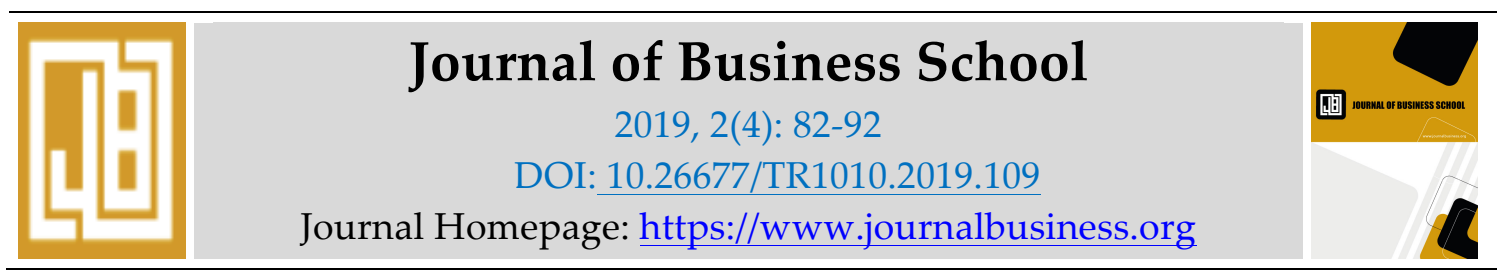

\title{
An Investigation of Factors Influencing Tax Evasion in Tanzania: A Case Study of Iringa Municipality
}

\author{
Emmanuel Hamis Mwandambo \\ Ruaha Catholic University
}

\begin{abstract}
Tax evasion is among the major societal problems inhibiting development in developing countries. Literature reveals that tax evasion also denote some of the difficulties in raising revenue in Tanzania and it generates inequity between the evaders and the honest taxpayers. The main purpose of this study was to investigate factors influencing tax evasion practices in Tanzania specifically in Iringa Municipality. Specifically, the study sought to examine the influence of multiplicity of tax to tax evasion, to identify how high tax rate leads to tax evasion, furthermore, to identify the manner in which tax revenue is spent contributes to tax evasion and finally, to determine whether the level of education/awareness of tax payers on tax influences tax evasion.

The study employed both quantitative and qualitative approaches (Mixed method) in the collection of relevant information. The study used descriptive research design while simple random and purposive sampling design were used in collecting data to a total of 100 respondents derived from a total population of 49,253 tax payers. Questionnaires used to obtain primary data while books, journals, dissertations and internet were used to obtain secondary data. Data was analyzed by using Statistical Package for Social Sciences (SPSS) software version 20 and Microsoft excel, while the results were summarized in tables of frequencies percentages and charts.

The results of the analysis showed that multiplicity of tax, high tax rate, the manner in which tax revenue is spent and education level have significant positive relationship with tax evasion. The study recommends that there should be an increase in education and counseling to tax payers; to educate the young who are the future taxpayers by creating an environment for tax education at schools, in additional, a number of taxes and tax rates should be reduced if cases of tax evasion have to be reduced; provision of proper social services to taxpayers, transparent in dealing with tax revenue and proper allocation of revenue collected.
\end{abstract}

Keywords: Tax, Tax Evasion, Iringa, Tanzania, Factors

\subsection{Background}

The desire to uplift one's society is the first desire of every patriotic citizen. Tax payment is a demonstration of such a desire (Adebisi \& Gbegi, 2013). Tax revenues allow the government to cover Revenue Goals such as administrative services, protective services, social services and development services. They also allow the government to cover Non-revenue Goals such as to 
protect domestic industries, to discourage certain habits, to regulate demand and supply in the economy in times of inflation (economic stabilization), income redistribution etc. For this purpose, taxation is a core source of revenue to the government and according to the law, it is an obligation of individuals and businesses to pay for it so that the government can obtain enough revenue to efficiently and effectively finance its expenditures.

Despite the fact that individuals and businesses, according to the law, have an obligation to pay tax to the government so that it can have enough revenue to finance its expenditures for the benefit of its citizens, what is prevailing in Iringa is that the majority of business owners, citizen and individuals evade to pay taxes to the respective authority. This is due to various reasons such as multiplicity of taxes, high tax rate and frequent change of tax rates, tax system, corruption among tax officials, level of education and awareness of taxpayers on tax and the manner in which the tax revenue is spent. Tax evasion is said to occur when individuals deliberately fail to comply with tax obligations. A real example is that, businesses either small or large are after profit maximization; since tax reduces their profit then they use different ways by which they can either reduce tax liability or not to pay tax at all. There are several ways used to reduce tax liability among them are overstating of expenses and understating sales revenue which results in lower taxable profit.

If this situation will continue to prevail in the country, the results due to tax revenue loss may cause serious damage on the performance of public sectors. Example, threatening the government capability to finance public expenditures, causing economic inequality, many projects to be kept on hold and welfare services to be kept aside. Due to that, the study investigates factors influencing tax evasion in Tanzania specifically Iringa Municipal so that tax payers can be educated to voluntarily pay their tax liability as well as help the policy makers (government) to formulate suitable tax policy.

\subsection{Literature Review}

\subsection{Multiplicity of tax and tax evasion}

According to Izedonmi (2010), multiple taxes is said to occur when the same income is subjected to more than one tax treatment. Multiple taxes make business entry difficult and expensive. If it is taxed twice then it is double taxation. When it is taxed thrice, it becomes triple taxation. An example of double taxation involves a situation where a company's profit is subject to corporate tax at corporate level and at the same time opened to withholding tax and PAYE as income tax in the hands of the investor.

Nongwa (2013) conducted an empirical study to examine the Efficacy of Anti-Avoidance Provisions under the Income Tax Act in Tanzania Mainland. The study found that multiplicity of tax is the one of the factors that tax payer hate paying tax thus noncompliance to tax issues which lead to reduction of revenue for the Government to operate. However, the researcher recommended that, tax laws should be harmonized so as to do away with the current multiplicity of tax laws which defeats taxpayers' positive perception to tax laws.

Akinwunmi, Olotu , \& Adegbie (2017) conducted a study with a title; "Multiplicity of Taxes and Foreign Direct Investment: A Relational Analysis of Nigerian Tax Environment". The emphasis of this study was to examine the relationship between multiple taxes and Foreign Direct Investment in flow in Nigeria for the period 1996 to 2015. The study adopted the ex-post facto research design and descriptive method. Secondary data used was collected from Central Bank of Nigeria Statistical bulletins, National bureau of statistics publications and Central Bank of Nigeria Annual Reports. Descriptive analytical procedure and inferential statistics were employed. The descriptive statistics was used in explaining the characteristics of the variables 
while inferential statistics involved the use of multiple regressions for analysis and time series was used for estimation. From the findings, it is noted that there is an inverse relationship between multiple taxes and Foreign Direct Investment (FDI) in Nigeria. It is therefore recommended that for Nigeria to secure a place as an economically viable nation in Africa, it must strive and achieve an internationally competitive tax system by eliminating all forms of multiple taxes in the country.

\subsection{Tax Rates and Tax Evasion}

Nyang'au, (2016), conducted an empirical study to investigate the causes of tax evasion and tax avoidance in Tanzania in Magu District. The study found that high tax rate has a positive and significant impact on tax evasion. The positive effect of tax rate implies that the higher the tax rates the more the likelihood of tax evasion and avoidance. Higher tax rates tempted people to evade and avoid tax because of the pinch associated with the higher tax rate.The researcher recommended that tax rates should be reduced so as to encourage tax payers not to evade and avoid tax. Another empirical study on high tax rate was conducted by Adebisi and Gbegi, (2013).The study aimed at examining the effect of tax avoidance and tax evasion on personal income tax administration in Nigeria. The research findings among others disclose that high tax rates on personal income encourage tax avoidance and tax evasion.

In addition, Hove and Hove (2016), conducted an empirical study on Investigating the Causes of Tax Avoidance and Tax Evasion in Zimbabwe: A Survey of Business Operators in Bulawayo. The study's sample frame was drawn from all tax registered companies in Bulawayo (SMEs and Large scale companies) and all ZIMRA employees working in Bulawayo. The researchers among others found that high tax rates encourage tax avoidance and tax evasion. The researcher recommended that the Government should review the tax percentage across various tax categories and better lower it than never.

\subsection{The manner in which tax revenue is spent and tax evasion}

The manner in which tax revenue is spent can be seen in two perspectives; one is transparency and accountability, and the other perspective is the quality of services in return. Lack of transparency and accountability in the use of public funds contributes to public distrust both with respect to the tax system as well as the government. This, in turn, increases the willingness to evade taxes (Kirchler, 2007). Furthermore, GIZ, 2010 added that if the government fails to provide basic public goods and services or provides them insufficiently, citizens may not be willing to pay taxes and tax evasion will be the consequence. Stephen, (2014), conducted an empirical study to Assess Tax Evasion Practices in Tanzania, a case of Temeke Municipal and found that accountability and improper utilizations of tax revenues contributes to tax evasion. Among others the researcher recommended that, Temeke Municipal Council should provide proper accountability for the tax revenue collected, and to ensure that public services are improved so as to increase payments of tax.

Asuamah, Amoah and Amaning (2014), conducted an empirical study with the title of "Investigation into Tax Evasion in Ghana and found tax evasion occurs if most of the money collected is spent unwisely and if the money collected is spent on projects that people do not benefit from, and when the money collected gets into the pockets of corrupt politicians. It is then recommended that tax policies must be fair and that tax officers must be encouraged to stay away from corrupt activities, and tax revenue should be spent on projects that will benefit the public as a whole. Another empirical study was conducted by Asumwisye (2014) with the title of "Tax Compliance in Local Government Authorities in Tanzania; A Case Study of Sumbawanga District Council" showed that, tax noncompliance behaviours such as tax evasion occurs due to unsatisfactory return in form of services delivery to the public. 


\subsection{The Level of Education and its influence on Tax Evasion}

Research has demonstrated that when people are educated about the importance of paying tax it re-awakens them and they become more conscious and responsible in paying their taxes promptly than the uneducated ones (Stamatopoulos, Vrantaki, \& Terzakis, 2015). Tumsifu (2015), conducted an empirical study which aimed at profiling attributes articulating SMEs' tax compliance in Tanzania. Findings among others showed that SMEs' tax compliance is influenced when reasons for paying tax are well known among tax payers and simplicity of tax laws. The study recommends to responsible institutions that they should simplify tax procedures, eliminate bureaucracies and educate tax payers for better compliance.

Berhane (2011) conducted an empirical study to examine the influence of tax education on the compliance attitude of tax payers, the study was conducted in Addis Ababa, Ethiopia. The findings indicated that tax compliance is influenced by tax education. Also Muzainah \& Zakariya'u (2016), conducted a study to assess the determinants of tax evasion in Gombe state (a state in Nigeria). The results shown that an adequate knowledge of taxes leads to a good understanding of tax laws and policies hence facilitates tax compliance and discourages tax evasion.

\subsection{The Research Gap and Conceptual Framework}

\subsubsection{The Research Gap}

Despite the fact that many researchers conducted different studies on tax evasion as stipulated in literature review above, there was no known study conducted in Iringa Municipality. This study, therefore, aimed to address this gap.

\subsubsection{Conceptual Framework}

The study proposed a conceptual framework based on the variable drawn from the study. Tax evasion is a dependent variable and factors influencing tax evasion is an independent variable. These two variables have been used by the researcher to see the relationship between these variables to investigate the factors influencing tax evasion.

The model as shown in the figure 1 below suggests that multiplicity of tax; high tax rate; the manner in which tax revenue is spent and level of education/awareness of tax are independent variables whereby Tax evasion is a dependent variable.

\section{INDEPENDENT VARIABLES DEPENDENT VARIABLE}

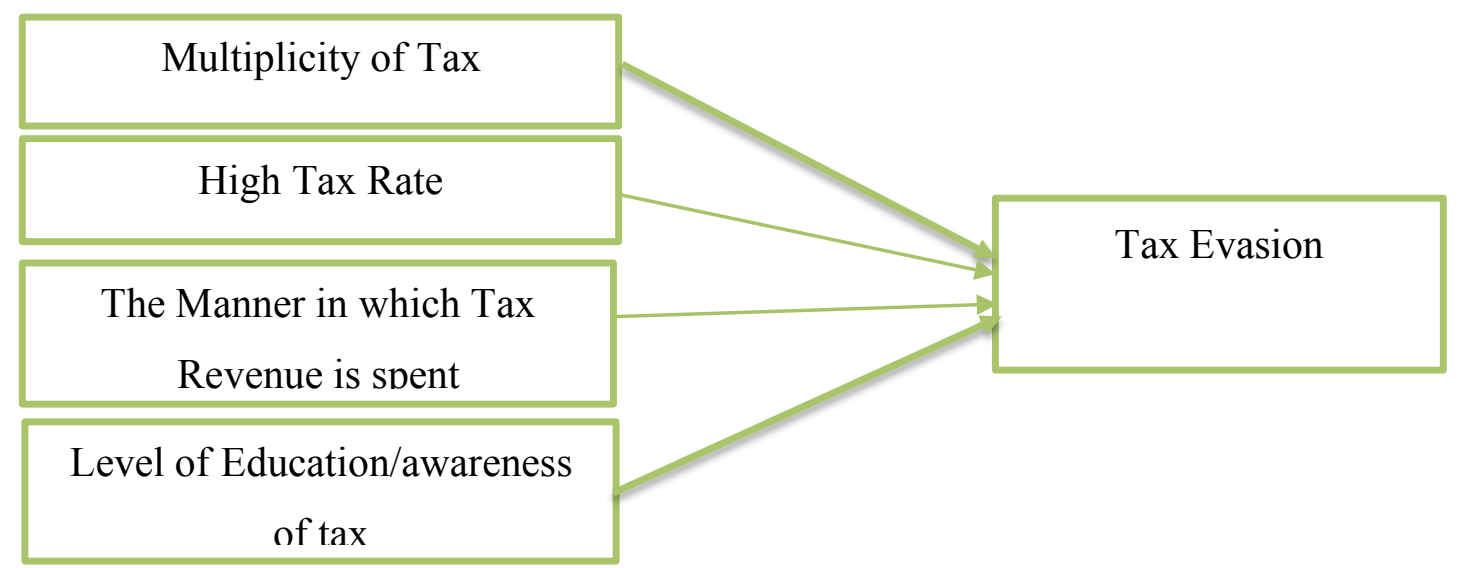

Figure 1 Conceptual Framework

Source: (Developed from literature review) 


\subsection{Research Methods}

The study employed quantitative method. The study used descriptive research design while simple random and purposive sampling design were used in collecting data to a total of 100 respondents derived from total population of 49,253 tax payers. Questionnaires were used to obtain primary data while books, journals, dissertations and internet were used to obtain secondary data. Data was analyzed by using Statistical Package for Social Sciences (SPSS) software version 20 and Microsoft excel; the results were summarized in tables of frequencies percentages and charts. Furthermore, the reliability of the data was measured by using the Cronbach's Alpha and the validity of the study was measured using the Kaiser-Meyer-Olkin (KMO) and Bartlett's Test of sphericity. Lastly, the researcher used correlation analyses to test the relationship exist between variables.

\subsection{Results}

\subsection{Demographic characteristics}

In this study, in order to have a better understanding on the demographic characteristics and specifications of the respondents, frequency analysis has been used. Findings as indicated in Table 1.

Table 1: Sample characteristics

\begin{tabular}{|l|l|c|c|}
\hline Variable & Categories & Frequency & Percentage (\%) \\
\hline Sex & Male & 66 & 66.0 \\
\cline { 2 - 4 } & Female & 34 & 34.0 \\
\hline Age & $18-24$ years & 15 & 15.0 \\
\cline { 2 - 4 } & 25-34 years & 43 & 43.0 \\
\cline { 2 - 4 } & 35-44 years & 27 & 27.0 \\
\cline { 2 - 4 } & 45-54 years & 11 & 11.0 \\
\cline { 2 - 4 } & 55 years and above & 4 & 4.0 \\
\hline \multirow{5}{*}{ Education Level } & Primary level & 2 & 2.0 \\
\cline { 2 - 4 } & Secondary level & 11 & 11.0 \\
\cline { 2 - 4 } & Certificate & 20 & 20.0 \\
\cline { 2 - 4 } & Diploma & 39 & 28.0 \\
\cline { 2 - 4 } & Degree & & 39.0 \\
\hline
\end{tabular}

Source: field data (2018)

The respondents were male 66 percent and female 34 percent. Most respondents were in the age group of 25-34years (43\%). Also majority (39\%) of the respondents were degree holders.

\subsection{Validity and Reliability}

\subsubsection{Reliability}

Table 2 shows the value of the coefficient alpha or Cronbach's alpha. The alpha coefficient for thirty five items is 0.924 , suggesting that the items have relatively high internal consistency. (Note that a reliability coefficient of 0.70 or higher is considered acceptable).

Table 2 Reliability Statistics

\begin{tabular}{|c|c|}
\hline Cronbach's Alpha & Number of Items \\
\hline .924 & 35 \\
\hline
\end{tabular}

Source: Field Data 2018 


\subsubsection{Validity}

Kaiser (1974) recommends KMO statistic a bare minimum of 0.5 and that values between 0.5 and 0.7 are mediocre, value between 0.7 and 0.8 are good, value between 0.8 and 0.9 are great and value above 0.9 are superb (Hutcheson \& Sofroniou, 1999). Therefore, KMO of 0.671 is acceptable while, Bartlet's test is significant at 0.05 .

Table 3 KMO and Bartlett's Test

\begin{tabular}{|l|l|l|l|}
\hline \multicolumn{2}{|l|}{ Kaiser-Meyer-Olkin Measure of Sampling Adequacy } & .671 \\
\hline Bartlett's Test of Sphericity & Approx. Chi-Square & & 2756.283 \\
\cline { 2 - 4 } & Df & 595 \\
\cline { 2 - 4 } & Sig. & .000 \\
\hline
\end{tabular}

Source: Field Data 2018

\subsection{Multiplicity of tax and tax evasion}

Data in table 4 suggests that $77 \%$ of the respondents declared that there are many taxes in Iringa Municipal and thus influences tax evasion, while $81 \%$ of the respondents agreed that many taxes erode savings or capacity to save and thus they decide to evade tax, $68 \%$ of the respondents consider multiple taxes as unfair therefore, they evade tax. $83 \%$ of the respondents agreed that multiple taxes are difficult to comply with that's why they are influenced to evade payments, $86 \%$ of the respondents agreed that when there are many taxes the decisions and confidence to invest are destroyed hence they evade tax payments, $76 \%$ of the respondents claimed that many taxes raises cost of doing business and $72 \%$ of the respondents claimed that paying many taxes leads to bankruptcy or shut down of production.

Table 4 Multiplicity of Tax and Tax Evasion (n=100)

\begin{tabular}{|c|c|c|c|c|c|}
\hline Statement & $\begin{array}{l}\text { Strongly } \\
\text { Disagree }\end{array}$ & Disagree & Neutral & Agree & $\begin{array}{c}\text { Strongly } \\
\text { Agree }\end{array}$ \\
\hline & $F(\%)$ & F (\%) & F (\%) & F (\%) & F (\%) \\
\hline There are many taxes & $2(2.0)$ & $10(10.0)$ & $11(11.0)$ & $39(39.0)$ & $38(38.0)$ \\
\hline $\begin{array}{l}\text { Erode savings or } \\
\text { capacity to save }\end{array}$ & $0(0.0)$ & $4(4.0)$ & $15(15.0)$ & $34(34.0)$ & $47(47.0)$ \\
\hline Multiple tax are unfair & $3(3.0)$ & $2(2.0)$ & $27(27.0)$ & $42(42.0)$ & $26(26.0)$ \\
\hline $\begin{array}{l}\text { Multiple taxes are } \\
\text { difficult to comply with }\end{array}$ & $2(2.0)$ & $2(2.0)$ & $13(13.0)$ & $52(52.0)$ & $31(31.0)$ \\
\hline $\begin{array}{l}\text { Destroys investors' } \\
\text { confidence }\end{array}$ & $1(1.0)$ & $1(1.0)$ & $12(12.0)$ & $39(39.0)$ & $47(47.0)$ \\
\hline $\begin{array}{l}\text { Raises cost of doing } \\
\text { business }\end{array}$ & $1(1.0)$ & $6(6.0)$ & $17(17.0)$ & $54(54.0)$ & $22(22.0)$ \\
\hline $\begin{array}{l}\text { Leads to bankruptcy or } \\
\text { shut down of production }\end{array}$ & $4(4.0)$ & $12(12.0)$ & $12(12.0)$ & $38(38.0)$ & $34(34.0)$ \\
\hline
\end{tabular}

$\mathrm{F}=$ Frequency, $\mathrm{n}=$ Sample Size

Source: Field Data 2018 


\subsection{Tax rates and its influence on tax evasion}

Results in table 5 indicates that, $80 \%$ of the respondents claimed that when the rate of tax is high, it erodes their profits thus reduces capacity to save and increase their capital then they evade to pay tax liability. $91 \%$ of the respondents claimed that high tax rates increase burden then they evade tax payments, $88 \%$ of the respondents disclosed that high rate imposed on tax leads to bankruptcy, also the table shows that $83 \%$ of the respondents declared that high tax rates discouraged their working morale, furthermore, $86 \%$ of the respondents claimed that high tax rate leads to lose of jobs. $85 \%$ of the respondents uncovered that high tax rate it is difficult to them to comply with and $80 \%$ of the respondents declared that high tax rate destroys decisions by multinational companies to invest in Tanzania. From the findings it is clear that there is a close relationship between high tax rate and tax evasion in Iringa Municipal.

Table 5 How High Tax Rate Leads to Tax Evasion (n=100)

\begin{tabular}{|c|c|c|c|c|c|}
\hline Statement & $\begin{array}{l}\text { Strongly } \\
\text { Disagree }\end{array}$ & Disagree & Neutral & Agree & $\begin{array}{c}\text { Strongly } \\
\text { Agree }\end{array}$ \\
\hline & F (\%) & F (\%) & F (\%) & F (\%) & F (\%) \\
\hline $\begin{array}{l}\text { Affects savings or } \\
\text { capacity to save }\end{array}$ & $1(1.0)$ & $3(3.0)$ & $3(3.0)$ & $38(38.0)$ & $55(55.0)$ \\
\hline Increase burden & $2(2.0)$ & $1(1.0)$ & $6(6.0)$ & $55(55.0)$ & $36(36.0)$ \\
\hline $\begin{array}{l}\text { Leads to bankruptcy or } \\
\text { shut down of production }\end{array}$ & $1(1.0)$ & $1(1.0)$ & $10(10.0)$ & $27(27.0)$ & $61(61.0)$ \\
\hline $\begin{array}{l}\text { Discourage work or will } \\
\text { to work }\end{array}$ & $0(0.0)$ & $6(6.0)$ & $11(11.0)$ & $34(34.0)$ & $49(49.0)$ \\
\hline Loss of jobs & $1(1.0)$ & $6(6.0)$ & $7(7.0)$ & $55(55.0)$ & $31(31.0)$ \\
\hline $\begin{array}{l}\text { High tax rates are } \\
\text { difficult to comply with }\end{array}$ & $1(1.0)$ & $3(3.0)$ & $11(11.0)$ & $37(37.0)$ & $48(48.0)$ \\
\hline $\begin{array}{l}\text { Jeopardize foreign direct } \\
\text { investment }\end{array}$ & $3(3.0)$ & $0(0.0)$ & $17(17.0)$ & $49(49.0)$ & $31(31.0)$ \\
\hline
\end{tabular}

$\mathrm{F}=$ Frequency, $\mathrm{n}=$ Sample Size

Source: Field Data 2018

\subsection{The Manner in Which Tax Revenue is Spent and Tax Evasion}

The majority of respondents agreed that tax evasion occurs when most of the money collected is spent unwisely, also if the money collected is spent on projects that they do not benefit from and the way decisions on allocating the collected revenue is made. However, the findings are summarized and presented in the table 6 below. $86 \%$ of the respondents agreed with the statement that lack of transparency on tax revenue utilization contributes to the tax evasion, $76 \%$ of the respondents claimed that lack of accountability of the government leads to tax evasion, also $77 \%$ of the respondents agreed that absence of direct equivalent benefit from what has been taxed or collected make them to decide not to pay tax. $89 \%$ of the respondents claimed that lack of quality goods and services in return for the tax revenue collected leads to tax evasion, $79 \%$ of the respondents indicated that wastage of public funds or abuse of public revenue discourage tax payers to voluntarily paying tax liability, while $77 \%$ of the respondents claimed that the way decisions on tax revenue allocation are made discourages them on paying tax thus evading tax. Finally, $77 \%$ of the respondents claimed that the manner tax revenue is utilized makes them evade tax. 
Table 6 The Manner in Which Tax Revenue is Spent and Tax Evasion (n=100)

\begin{tabular}{lccccc}
\hline \multicolumn{1}{c}{ Statement } & $\begin{array}{l}\text { Strongly } \\
\text { Disagree }\end{array}$ & Disagree & Neutral & Agree & $\begin{array}{c}\text { Strongly } \\
\text { Agree }\end{array}$ \\
\hline & $\mathbf{F ~ ( \% )}$ & $\mathbf{F ~ ( \% )}$ & $\mathbf{F ~ ( \% )}$ & $\mathbf{F ~ ( \% )}$ & F (\%) \\
$\begin{array}{l}\text { Lack of transparency on tax } \\
\text { revenue utilization }\end{array}$ & $4(4.0)$ & $1(1.0)$ & $9(9.0)$ & $48(48.0)$ & $38(38.0)$ \\
$\begin{array}{l}\text { Lack of accountability of } \\
\text { the government }\end{array}$ & $0(0.0)$ & $6(6.0)$ & $19(19.0)$ & $51(51.0)$ & $24(24.0)$ \\
$\begin{array}{l}\text { No direct equivalent } \\
\text { benefit or absence of Quid } \\
\text { Pro Quo relationship }\end{array}$ & $2(2.0)$ & $3(3.0)$ & $18(18.0)$ & $50(50.0)$ & $27(27.0)$ \\
$\begin{array}{l}\text { Lack of quality goods and } \\
\text { services in return }\end{array}$ & $2(2.0)$ & $1(1.0)$ & $8(8.0)$ & $59(59.0)$ & $30(30.0)$ \\
$\begin{array}{l}\text { Wastage of public } \\
\text { funds/abuse of tax revenue }\end{array}$ & $1(1.0)$ & $1(1.0)$ & $19(19.00$ & $50(50.0)$ & $29(29.0)$ \\
$\begin{array}{l}\text { Poor decisions on tax } \\
\text { revenue allocation }\end{array}$ & $3(3.0)$ & $2(2.0)$ & $18(18.0)$ & $45(45.0)$ & $32(32.0)$ \\
\hline Leads to tax evasion & $0(0.0)$ & $2(2.0)$ & $11(11.0)$ & $32(32.0)$ & $55(55.0)$ \\
\hline
\end{tabular}

$\mathrm{F}=$ Frequency, $\mathrm{n}=$ Sample Size

Source: Field Data 2018

\subsection{The Level of Education/Awareness of Tax Payers and Tax Evasion}

The majority of the respondents revealed that the level of education or awareness or knowledge about tax change the attitudes of tax payers towards tax evasion, thus, inadequate knowledge or lack of knowledge about tax will increase the possibility of evading tax payments. Findings from table 7 depicts that $75 \%$ of the respondents claimed that inadequate knowledge about the reasons of paying tax makes the tax payers evade tax payments, $83 \%$ of the respondents declared that tax knowledge is the influential factor towards tax payments, while $69 \%$ of the respondents declared that when tax payers provided less training or seminar about taxes by tax administrator will increase the possibility of tax payers to evade tax. $81 \%$ of the respondents agreed that inadequate knowledge about tax laws contributes to tax evasion practices, furthermore, $87 \%$ of the tax payers claimed that lack of technical knowledge in determining tax liability influences tax evasion, $80 \%$ of the respondents showed that inadequate access of information about tax leads to tax evasion and $82 \%$ of the respondents claimed that tax education or knowledge enables tax payers to obey tax laws and prompt paying tax liability.

Table 7 How Level of Education/Awareness about Tax Influences Tax Evasion (n=100)

\begin{tabular}{lccccc}
\hline \multicolumn{1}{c}{ Statement } & $\begin{array}{c}\text { Strongly } \\
\text { Disagree }\end{array}$ & Disagree & Neutral & Agree & $\begin{array}{c}\text { Strongly } \\
\text { Agree }\end{array}$ \\
\hline & $\mathbf{F ~ ( \% )}$ & $\mathbf{F ~ ( \% )}$ & F (\%) & F (\%) & F (\%) \\
$\begin{array}{l}\text { Inadequate knowledge of } \\
\text { reasons for paying tax }\end{array}$ & $2(2.0)$ & $12(12.0)$ & $11(11.0)$ & $43(43.0)$ & $32(32.0)$ \\
$\begin{array}{l}\text { Tax knowledge is the } \\
\text { influential factor for tax } \\
\text { payment }\end{array}$ & $2(2.0)$ & $2(2.0)$ & $13(13.0)$ & $33(33.0)$ & $50(50.0)$ \\
\hline
\end{tabular}




\begin{tabular}{lccccc}
\hline $\begin{array}{l}\text { Lack of frequent } \\
\text { training/seminar to tax } \\
\text { payers }\end{array}$ & $2(2.0)$ & $3(3.0)$ & $26(26.0)$ & $42(42.0)$ & $27(27.0)$ \\
$\begin{array}{l}\text { Inadequate knowledge } \\
\text { about tax laws }\end{array}$ & $2(2.0)$ & $12(12.0)$ & $11(11.0)$ & $43(43.0)$ & $32(32.0)$ \\
$\begin{array}{l}\text { Lack of technical } \\
\text { knowledge in determining } \\
\text { tax liability }\end{array}$ & $0(0.0)$ & $3(3.0)$ & $10(10.0)$ & $27(27.0)$ & $60(60.0)$ \\
$\begin{array}{l}\text { Inadequate access of } \\
\text { information about tax }\end{array}$ & $2(2.0)$ & $5(5.0)$ & $13(13.0)$ & $61(61.0)$ & $19(19.0)$ \\
$\begin{array}{l}\text { Tax education or } \\
\text { knowledge enable tax } \\
\text { payers to obey tax law }\end{array}$ & $9(9.0)$ & $12(12.0)$ & $15(15.0)$ & $29(29.0)$ & $35(35.0)$ \\
\hline F= Frequency, N= Sample Size & & & & & \\
\hline
\end{tabular}

Source: Field Data 2018

\subsection{Conclusion and Recommendation}

\subsection{Conclusion}

The study concludes that multiplicity of tax positively and significant influence tax evasion in Iringa, this implies that, the lower the tax the higher the likelihood of reducing tax evasion. High tax rate positively and significantly influence tax evasion in Iringa. This indicates that the higher the tax rate the higher the likelihood of tax evasion occurrence. Moreover, it was concluded that the manner in which tax revenue is spent found to be positively and significantly influence tax evasion, this implies that, the more responsible the government is in terms of provision of quality services, transparency and better allocation of revenue collected the more the likelihood of reducing tax evasion; and lastly, education level positively and significantly influence tax evasion in Iringa, this means that, the higher the education on the part of the tax payers the higher the chances of reducing the likelihood of tax evasion.

\subsection{Recommendation}

Based on the study findings, it was observed that in order to increase voluntary tax compliance and overcome problem of tax evasion the following steps should be taken into consideration.

i. Provision of education and tax counseling to tax payers on the significance of paying tax to the Government because education provided is not enough thus many individuals perceived that taxation is the difficult subject.

ii. Keeping marginal rates of tax low so as encourage tax payers not to evade and avoid tax.

iii. It is said that taxpayers tend to comply with tax rules if it is easier and cheaper for them to pay taxes. Reducing the complex procedure for tax payment and provision of guidance on how to improve bookkeeping and tax returns perhaps can increase tax payment prompt.

iv. Government should provide proper social services to the taxpayers, transparent in its dealings and proper allocation of revenue collected. 
v. Multiple taxation is harmful to businesses as they promote uncertainty and unlock the channel for revenue leakages. The government should review its tax system in order to make as fewer as possible number of taxes to increase tax payment morale.

vi. Penalty provisions. The penalty for fraud, default, etc. must be imposed consistently. The tax authorities should undertake criminal prosecution in respect of cases involving fraud or evasion, and where appropriate publish the names of tax evaders which will act as a deterrent.

\subsection{References}

Adebisi, J. F., \& Gbegi, D. O. (2013). Effect of Tax Avoidance and Tax Evasion on Personal Income Tax Administration in Nigeria. American Journal of Humanities and Social Sciences Vol 1 Issue 3, Pg 125-134.

Akinwunmi, A. J., Olotu, A. E., \& Adegbie, F. F. (2017). Multiplicity of Taxes and Foreign Direct Investment: A Relational Analysis of Nigerian Tax Environment. Social Sciences Vol 6 Issue 4, Pg 91-101.

Asuamah, S. Y., Amoah, R., \& Amaning, N. (2014). An Investigation into Tax Evasion in Ghana. International Journal of Empirical Finance Vol 2 Issue 3, Pg 115-122.

Asumwisye, K. M. (2014). Tax Compliance in Local Government Authorities in Tanzania. Sumbawanga District Council: Mzumbe University.

Berhane, Z. (2011). The Influence of Tax Education on Tax Compliance Attitude. Addis Ababa Ethiopia: Addis Ababa University.

GIZ Sector Programme Public Finance, A. R. (2010). Addressing tax evasion and avoidance in developing countries. Eschborn, German: Deutsche Gesellschaft fur Internationale Zusammenarbeit (GIZ) GmbH.

Hove, K., \& Hove, R. F. (2016). Investigation into the Causes of Tax Avoidance and Tax Evasion in Zimbabwe: A Survey of Business Operators in Bulawayo. International Journal of Economics, Commerce and Management Vol IV Issue 5, Pg 512-531.

Hutcheson, G. D., \& Sofroniou, N. (1999). TheMultivariate Social Scientist: Introduction Statistics Using Generalized Linear Models. SAGE Publications.

Izedonmi, F. (2010). the capital market perspective. Eliminating multiple taxation in the capital market. Benin City: A paper presented at the University of Benin.

Kaiser, H. F. (1974). An Index of Factor Simplicity. Psychometrika Vol 39 Issue 1, Pg 31-36.

Kirchler, E. (2007). The Economic Psychology of Tax Behaviour. Cambridge: Cambridge University Press.

Muzainah, M., \& Zakariya'u, G. (2016). The Determinants of Tax Evasion in Gombe State Nigeria. International Journal of Economics and Financial Issues, Pg 165-170.

Nongwa, V. M. (2013). Tax avoidance in Tanzania mainland: the law and practice of anti-avoidance provisions under the income tax act no.11 of 2004. Mzumbe University.

Nyang'au, S. N. (2016). An investigation of the causes of tax evasion and tax avoidance in Tanzania: A case study of Magu district. International Journal of Humanities and Social Science Research, Pg 17-20. 
Stamatopoulos, Vrantaki, \& Terzakis. (2015). On the Inhuman act of Tax Evasion: Is there Progress in Economic Scientific Knowledge? International Journal of Business Humanities and Technology, Pg 60-80.

Stephen, G. (2014). assessment of Tax Evasion Practices in Tanzania: A case of Temeke Municipal - A Dissertation. Dar es Salaam: Mzumbe University Dar es Salaam Campus College.

Tumsifu, E. (2015). Attributes articulating SMEs' tax compliance in Tanzania. ORSEA Journal Vol 5 Issue 1, Pg 54-75. 